\title{
PEMBERDAYAAN PERTANIAN LOKAL DALAM MENOPANG KEBERHASILAN PROGRAM FOOD ESTATE DI KALIMANTAN TENGAH
}

\author{
Abdul Mukti \\ Staf Pengajar Program Studi Agribisnis Fakultas Pertanian Univesitas Palangka Raya \\ Email: abdulmukti.1201@gmail.com
}

\begin{abstract}
ABSTRAK
Pembangunan Food estate di Kalimantan Tengah akan dilakukan dengan intensifikasi lahan pertanian yang sudah ada dengan cara meningkatkan indeks pertanaman. Pengagendaan ketahanan pangan tergantung keberadaan isu yang memang mengancam, keinginan politik aktor dalam sekuritisasi, bayangan keuntungan masa depan yang akan didapat, juga jejaring lokal dan nasional yang dibangun untuk mendukung proses tersebut, dan faktor yang memperlemahnya adalah kondisi politik yang kerap berubah. Terdapat disjungsi antara kebijakan terkait keamanan pangan dan bentuk-bentuk kemiskinan pangan yang dialami, dan menimbulkan keraguan atas konsistensi internal kebijakan. Akibat implementasi yang belum matang, capaian keberhasilan program MIFEE sebelumnya masih relatif lambat. Telah diidentifikasi sejumlah masalah dalam meningkatkan produksi beras, seperti penguasaan lahan, kesesuaian lahan, sistem air, infrastruktur, aksesibilitas faktor produksi, kelembagaan, dan kapasitas sumber daya manusia. Proyek modernisasi pertanian dalam skala luas di Merauke dan Bulungan bukanlah usaha menjaga ketahanan pangan, melainkan semata ekspansi agribisnis dalam skala luas. Solusi yang ditawarkan adalah bahwa pelaku utama pembangunan Food estate ini terutama adalah para petani setempat. Kewajiban pemerintah adalah membantu mereka dengan menciptakan iklim, di mana para pelaku pembangunan ini bersedia dan mampu melakukan pembangunan Food estate yang sukses sebagaimana yang diharapkan. Setiap petani mempunyai kebebasan memilih, jenis pembangunan Food Estate apa yang akan mereka lakukan, bagaimana caranya, dan bilamana pembangunan itu akan dilakukan, untuk apa hasilnya nanti akan digunakan, dan sebagainya. Pemerintah hanya mengarahkan hak pilih petani dengan mengatur keadaan yang ada di sekitar petani.
\end{abstract}

Kata-kata Kunci : food estate, ketahanan pangan, implementasi, solusi

\begin{abstract}
Food estate development in Central Kalimantan will be carried out by intensifying existing agricultural land by increasing the cropping index. The agenda for food security depends on the existence of a threatening issue, the political will of the actors in securitization, the image of future benefits that will be obtained, as well as local and national networks that are built to support this process, and the factor that weakens it is the changing political conditions. There is a disjunction between policies related to food security and the forms of food poverty experienced, and raises doubts over the internal consistency of the
\end{abstract}


policy. Due to the immature implementation of the MIFEE program, the achievements of the previous MIFEE program were relatively slow. A number of problems have been identified in increasing rice production, such as land tenure, land suitability, water systems, infrastructure, accessibility of production factors, institutions, and human resource capacity. The large scale agricultural modernization project in Merauke and Bulungan is not an effort to maintain food security, but merely an expansion of agribusiness on a large scale. The solution offered is that the main actors in the development of this food estate are mainly local farmers. The government's obligation is to help them by creating a climate in which these development actors are willing and able to carry out successful Food estate developments as expected. Every farmer has the freedom to choose, what type of Food Estate development they will do, how, and when the construction will be carried out, what the results will be used for, and so on. The government only directs farmers' suffrage rights by regulating the existing conditions around the farmers.

\section{Keywords : food estate, food security, implementation, solution}

\section{PENDAHULUAN}

Food estate sudah merupakan salah satu Program Strategis Nasional 2020-2024 yang bertujuan membangun lumbung pangan nasional. Pembangunan Food estate di Kalimantan Tengah (Kalteng) tidak akan membuka kembali lahan eks pengembangan lahan gambut (PLG). Pembangunan akan dilakukan dengan intensifikasi lahan pertanian atau mengoptimalkan pemanfaatan lahan eks PLG dan non eks PLG yang sudah ada dengan cara meningkatkan indeks pertanaman. Pengoptimalan itu dilakukan dengan penerapan teknologi 4.0, seperti pemberian bibit unggul (perbaikan varietas), pemupukan berimbang, dan penggunaan alat mesin pertanian (alsintan), sehingga ditargetkan produktivitas bisa mencapai 7 ton/hektar. Kegiatan intensifikasi awal tahun 2020 ini seluas 30.000 hektar, meliputi 20.000 hektar di Kabupaten Kapuas dan 10.000 hektar di Kabupaten Pulang Pisau. Pemerintah Pusat juga merencanakan peningkatan penanganan pascapanen dan berupaya mewujudkan pertanian modern agar tidak kalah dengan pertanian di Pulau Jawa. Food estate berbasis korporasi itu merupakan investasi terintegrasi dari hulu ke hilir sebagai upaya meningkatkan produksi pangan bagi masyarakat Indonesia. Pengembangan Food estate ini merupakan program dan sinergi seluruh komponen pada pemerintah pusat dan daerah dengan dukungan pengawasan serta pembiayaannya. Sinergi itu mulai dari sistem hulu, on farm, hilir, hingga distribusi pasar untuk meningkatkan kapasitas dan diversifikasi produksi pangan (Limpo, 2020). Selanjutnya Sarwo Edhy (2020), Peralatan dan mesin-mesin pertanian (alsintan) diperlukan untuk mendukung pembangunan Food estate. Alsintan itu, antara lain traktor roda 4 dan 2, pompa air, rice transplatter, hand sprayer, drone tabur benih, dan combine harvester. Kementerian Pertanian juga menyiapkan benih sekitar 1.500 ton, dolomit 30.000 ton, pupuk hayati 150.000 ton, urea 6000 
ton, NPK 4500 ton, dan pupuk herbisida 120.000 ton.

Nantinya, Food estate akan berada pada lahan seluas 165.000 hektar. Food estate menjadi upaya pemerintah RI untuk mengantisipasi ancaman krisis pangan sebagai dampak pandemi Covid-19. Pembangunannya pun mengintegrasikan pertanian, perkebunan, dan peternakan pada satu kawasan. Presiden menyatakan bahwa Food estate ini yang bertanggung jawab pada produksinya adalah Mentan yang bersinergi dengan kementerian lainnya.. Ia melanjutkan, aktivitas di sana tidak hanya produksi. BUMN akan bertanggung jawab membangun industri, yakni terlibat dalam pemrosesan hingga pengemasan. Para petani dan peternak di sana selanjutnya akan terkonsolidasi dalam kelompok-kelompok tani dengan terlebih dahulu difasilitasi, baik sarana maupun prasarana serta pendukung lainnya. Komoditas pangan dari Food Estate ini nantinya juga akan beragam, tidak hanya padi dan jagung. Sarana produksi dan infrastruktur pertanian juga akan dibangun, seperti embung, irigasi, hingga sarana pascapanen yang modern. Sebagai info, Kalteng ternyata berhasil mengembangkan Padi Inbrida Varietas Unggul Baru Inpari-42 dan Padi Hibrida SUPADI. Selain itu, Kalteng juga sukses memproduksi jagung untuk kebutuhan nasional. Pada 2015, produksi jagung mencapai 8.940 ton pipilan kering dan tahun 2019 sebesar 71.000-118.000 ton pipilan kering atau naik hampir 1.000 persen.

Menteri Pekerjaan Umum dan Perumahan Rakyat ( PUPR) Basuki Hadimuljono mengatakan, lahan potensial seluas 165.000 hektar eks-
Pengembangan Lahan Gambut (PLG) di Kalimantan Tengah siap berproduksi pada tahun 2022 mendatang. Lahan ini akan dikerjakan mulai tahun 2020 ini sampai 2022. Targetnya, pada tahun 2022 mendatang lahan seluas 165.000 hektar sudah bisa dioptimalkan produksinya. Rinciannya, 85.500 hektar merupakan lahan fungsional yang siap digunakan untuk berproduksi setiap tahun. Dari jumlah tersebut, 28.300 hektar masih dalam kondisi irigasi baik dan 57.200 hektar perlu dilakukan rehabilitasi jaringan irigasi. Sementara, 79.500 lahan sudah berupa semak belukar sehingga perlu dilakukan pembersihan (land clearing) atau tanpa perlu dilakukan pencetakan sawah kembali. Hal tersebut dilakukan untuk mendukung Pemerintah dalam menciptakan kawasan yang mengintegrasikan pertanian, perkebunan, dan peternakan guna menjamin kebutuhan dan ketahanan pangan Nasional. Food estate ini merupakan suatu daerah yang ditetapkan sebagai lumbung pangan baru di Indonesia. Lokasi lumbung pangan baru yang juga merupakan bagian dari Program Strategis Nasional (PSN) Tahun 2020 hingga 2024 tersebut berada di Kabupaten Pulang Pisau, Provinsi Kalimantan Tengah.

Secara rinci, luas lahan 1.210 hektar siap dikerjakan pada tahun 2020, 33.335 hektar lahan dikerjakan pada tahun 2021, serta 22.655 hektar akan dikerjakan tahun 2022. Adapun total kebutuhan anggaran untuk pekerjaan tersebut sebesar $\mathrm{Rp} 1,05$ triliun. Basuki mengungkapkan, pengembangan program food estate ini akan dilakukan bersama Kementerian BUMN melalui skema investasi. Kementerian PUPR mengembangkan sarana dan 
prasarana dasar seperti perbaikan saluran-saluran irigasi di sekitar kawasan tersebut baik jaringan irigasi sekunder maupun primer. Sementara, Kementerian BUMN bersama Kementerian Pertanian akan melakukan pengembangan teknologi olah tanam.

\section{PROGRAM DAN IMPLEMENTASI SEBELUMNYA}

Kebutuhan akan pangan merupakan kebutuhan primer setiap manusia yang tidak bisa tergantikan, hal ini menyebabkan pangan mempengaruhi kehidupan manusia dari berbagai sektor baik itu sektor ekonomi, sosial, politik ataupun budaya (Khudori, 2008). Dikarenakan begitu pentingnya peran pangan, maka PBB memiliki lembaga khusus untuk menangani isu pangan yaitu FAO. FAO berhasil membuat negara anggota PBB memprioritaskan kebijakan pangan, termasuk Indonesia (Putri, 2019).

Menurut Putri (2019) bahwa di Indonesia sendiri, tindakan pengagendaan isu pangan sebagai isu keamanan bukanlah hal baru. Semenjak Indonesia merdeka hingga sekarang, pangan masih dianggap sebagai isu strategis. Walaupun begitu, proses pengagendaan isu pangan menjadi isu keamanan berbeda-beda di setiap masa ke pemerintahan presiden Indonesia, hal ini dikarenakan Indonesia menganut sistem presidensial. Di era pemerintahan SBY sekuritisasi pangan melahirkan sebuah kebijakan yang bernama Food Estate (FE) atau kebijakan pangan skala luas. FE merupakan salah satu kebijakan strategis SBY dalam program kerja 100 hari kabinet Indonesia Bersatu. Selain itu, perintisan kebijakan ini telah dikeluarkan melalui beberapa kebijakan pemerintahan SBY sebelumnya yaitu Revitalisasi Pertanian, Perikanan, dan Kehutanan, serta kebijakan umum dewan ketahan pangan 2005-2009 dan 2010-2014.

Kebijakan FE merupakan salah satu tindakan darurat yang dilakukan pemerintah untuk menanggulangi krisis pangan (Dewan Ketahanan Pangan, 2009). Kebijakan FE sebagai bentuk dari tindakan darurat dalam implementasinya dilakukan dalam sebuah bentuk prosedur khusus, di mana dalam implementasinya bisa saja tidak mematuhi dan melanggar aturan-aturan yang sudah ada. Contohnya adanya izin melakukan penebangan hutan dan membuka lahan gambut padahal di saat yang bersamaan Indonesia dalam forumforum internasional yang membahas perubahan iklim telah berkomitmen untuk menurunkan emisi gas rumah kaca dan menjaga hutan yang dianggap sebagai paru-paru dunia (Greenomics Indonesia, 2011). Selain itu, dalam pembebasan lahan, pemerintah ikut serta secara proaktif untuk mengambil tanah milik masyarakat dan diserahkan kepada perusahaan walaupun di saat yang bersamaan terjadi penentangan dari masyarakat setempat dan adanya advokasi dari NGO baik nasional maupun internasional (Putri, 2019).

Pasca dilantiknya Joko Widodo pada tahun 2014 dan 2019, beberapa kebijakan yang pernah dikeluarkan oleh pendahulunya Soesilo Bambang Yudhoyono (SBY) dihapuskan. Salah satunya adalah kebijakan pangan skala besar (Food Estate). Lebih jauh, saat ini Jokowi bahkan tidak menjadikan isu pangan sebagai salah satu isu prioritas dalam kebijakan pemerintahannya. Dalam pidato kemenangannya pada tahun 2019, 
jokowi fokus pada isu pengembangan sumber daya manusia, sedangkan pada tahun 2014 Jokowi fokus pada pengembangan kemaritiman (Putri, 2019).

Selanjutnya dari penelitian Putri (2019) menyimpulkan bahwa kesuksesan pengagendaan isu pangan ini didorong oleh beberapa faktor yaitu keberadaan isu yang memang mengancam, keinginan politik aktor dalam sekuritisasi, bayangan keuntungan masa depan yang akan didapat, juga jejaring lokal dan nasional yang dibangun untuk mendukung proses tersebut. Sedangkan faktor yang memperlemah sekuritisasi adalah kondisi politik yang kerap berubah seiring bergantinya kebijakan juga kekuatan yang dimiliki oleh veto actors dalam membangun jejaring untuk menentang sekuritisasi.

McCarthy, J.F., and K. Obidzinski (2015) bahwa sejak tahun 2008, ketika para pembuat kebijakan di negara-negara berkembang menyulap tujuan-tujuan yang saling bersaing, bidang kebijakan yang saling bertentangan muncul seputar masalah ketahanan pangan. Makalah ini mengembangkan kerangka kerja untuk mempertimbangkan pertanyaan normatif yang mendasari pilihan kebijakan dan memetakan implikasi pilihan yang berbeda untuk kemiskinan dan ketidaksetaraan pangan. Menerapkan ini untuk kasus Kalimantan Indonesia, makalah ini berfokus pada tiga pendekatan yang paling menonjol dengan implikasi substansial untuk penggunaan lahan. Ini termasuk skema ekstensifikasi untuk membuka perkebunan padi baru; program intensifikasi yang berupaya memodernisasi praktik pertanian dengan meningkatkan produksi di wilayah yang ada; dan ketiga, kebijakan yang mendukung penutupan cepat daerah dataran tinggi dan transformasi mereka selanjutnya menjadi konsesi kelapa sawit skala besar, tanaman tunggal. Makalah ini menggambarkan tiga pendekatan kebijakan ke dalam dialog dengan konsep 'ketahanan pangan' 'kedaulatan pangan' dan 'hak atas pangan' di samping prinsip-prinsip ekologis. Ini mengungkapkan disjungsi antara kebijakan terkait keamanan pangan dan bentuk-bentuk kemiskinan pangan yang dialami, menimbulkan pertanyaan mengenai konsistensi internal kebijakan, dan merekomendasikan mencari pendekatan baru yang sesuai dengan konteks tertentu dan yang dapat ditingkatkan

Santosa, E., (2014) bahwa pemerintah telah melakukan berbagai terobosan untuk perluasan lahan pangan, salah satunya melalui pengembangan pangan skala luas (food estate). Program Merauke Integrated Food and Energy Estate (MIFE) merupakan food estate yang dinotifikasi secara nasional yaitu Energy Estate di Kabupaten Merauke, Papua seluas 1,2 juta ha, namun proyek food estate tersebut belum dapat berjalan sesuai harapan karena berbagai kendala yang kompleks. Akibat implementasi yang belum matang, capaian keberhasilan MIFEE pada saat ini masih relatif lambat. Oleh karena itu, perlu dicari alternatif solusi agar MIFEE dapat menjadi tonggak sejarah sekaligus legacy pembangunan pangan untuk generasi mendatang. Permasalahan MIFEE dari segi investor, kelembagaan, perundang-undangan, sosial, budaya dan politik dianalisis dan dicarikan solusi nya.

Setyo, P., and Elly J, (2018) Untuk meningkatkan produksi beras di 
$\begin{array}{lrr}\text { Provinsi } & \text { Kalimantan } & \text { Utara, } \\ \text { pemerintah } & \text { provinsi } & \text { telah }\end{array}$ meluncurkan Program Food estate. Program ini juga merupakan program pemerintah pusat terkait dengan kebijakan pemerintah tentang ketahanan pangan. Salah satu pengembangan food estate Delta Kayan Food Estate seluas 50.000 hektar di Kabupaten Bulungan, di mana Area sekitar 30.000 hektar adalah tanah pasang surut dengan jenis tanah aluvial yang sangat subur. Studi kebijakan ini bertujuan untuk mengidentifikasi dan menganalisis masalah peningkatan produksi beras melalui pengembangan food estate di Provinsi Kalimantan Utara Indonesia dan merumuskan program prioritas sebagai rekomendasi untuk membuat kebijakan dalam meningkatkan produksi beras. Studi ini telah mengidentifikasi sejumlah masalah meningkatkan produksi beras, seperti penguasaan lahan, kesesuaian lahan, sistem air, infrastruktur, aksesibilitas faktor produksi, kelembagaan, dan kapasitas sumber daya manusia. Analitik Proses Hirarki diterapkan untuk mengembangkan program prioritas, menghasilkan tiga yang program paling penting adalah pengelolaan air, peningkatan akses ke faktor produksi, dan meningkatkan kapasitas sumber daya manusia. Rencana aksi terkait dengan program prioritas juga ada telah diidentifikasi. Sagala (2018) Hasil pembahasan dari permasalahan yang timbul dalam penelitian ini adalah Pengaturan hukum tentang pengambilalihan hak atas tanah dari masyarakat petani guna pelaksanaan program food estate dikaitkan dengan batas maksimum luas tanah yang dapat dimiliki oleh perorangan maupun badan hukum berdasarkan UndangUndang No. 56 Prp Tahun 1960
Tentang Penetapan Luas Tanah bertentangan dengan PP No. 18 Tahun 2010. Pelaksanaan program food estate di Kabupaten Bulungan Provinsi Kalimantan Timur dan Kabupaten Merauke juga bertentangan dengan PP No. 18 Tahun 2010 dalam hal batas maksimum luas tanah yang boleh dikuasai untuk pelaksanaan usaha budidaya tanaman oleh investor. Peralihan hak atas tanah untuk kebutuhan program food estate dalam rangka ketahanan pangan berdasarkan PP No. 18 Tahun 2010 tentang Usaha Budidaya Tanaman dikaitkan dengan UUPA adalah pihak perusahaan (investor) yang membutuhkan lahan pertanahan untuk kepentingan program food estate wajib melakukan ganti rugi atas lahan pertanahan milik petani. Perlindungan hukum terhadap pemilik hak atas tanah dalam pelaksanaan program food estate melalui usaha budidaya tanaman dikaitkan dengan hukum positif Indonesia adalah bahwa pemilik hak atas tanah tidak boleh diperlakukan secara sewenang-wenang, dalam pelaksanaan peralihan hak atas tanah harus dilakukan dengan cara ganti rugi berdasarkan kesepakatan sesuai harga pasar antara petani selaku pemilik tanah dan investor.

Transmigrasi selama ini terkait dengan upaya menggenjot produktivitas pangan. Pada masa Orde Baru, transmigrasi digalakkan dengan untuk menjadikan transmigran sebagai tenaga kerja murah di perkebunan besar milik pemerintah. Setelah masa Orde Baru berakhir, transmigrasi dijadikan lagi sebagai penopang program pangan dengan dicetuskannya proyek food estate. Kajian ini ingin mendalami paradoks dari proses modernisasi pertanian skala luas melalui proyek 
food estate yang justru menyebabkan dampak negatif bagi petani transmigran dan penduduk lokal. Penelitian ini merupakan studi literatur yang dilakukan dengan melakukan penelusuran terhadap laporan penelitian, dokumen pemerintahan, artikel jurnal, dan berita dari berbagai media yang terkait dengan pelaksanaan food estate. Analisis data dilakukan melalui beberapa tahapan, yakni reduksi data, penyajian data, verifikasi dan penarikan kesimpulan. Kajian ini telah menemukan bagaimana proyek modernisasi pertanian dalam skala luas di Merauke dan Bulungan bukanlah usaha menjaga ketahanan pangan, melainkan semata ekspansi agribisnis dalam skala luas. Penyelenggaraan transmigrasi pada dasarnya hanya menjadi penopang untuk memfasilitasi ekspansi agribisnis yang terjadi di Merauke dan Bulungan. Kajian ini telah membuktikan kondisi kerawanan pangan yang harus dihadapi petani transmigran dan penduduk lokal terdampak proyek.

\section{PEMBERDAYAAN PERTANIAN LOKAL SEBAGAI SOLUSI UTAMA}

Pelaku utama pembangunan food estate di Kalimantan Tengah ini terutama adalah para petani setempat. Akan tetapi tidak bisa diabaikan peran pelaku pembangunan lain yang harus dilibatkan yakni para pengusaha swasta di bidang pertanian, dan BUMN yang ditugaskan oleh Pemerintah untuk berusaha pada pembangunan food estate ini. Keterlibatan BUMN bukan berarti tidak ada lagi kewajiban pemerintah dalam pembangunan food estate ini. Kewajiban pemerintah yang utama adalah membantu mereka dengan menjalankan berbagai usaha yang dapat menciptakan suatu iklim, di mana para pelaku pembangunan ini bersedia dan mampu melakukan pembangunan food estate yang sukses sebagaimana yang diharapkan.

Bersedia, karena menyadari bahwa pembangunan ini, di samping bermanfaat untuk masyarakat juga akan memberikan laba pula kepada diri mereka sendiri. Mampu, karena mereka mempunyai alat-alat, keterampilan, kecakapan, dan pengetahuan untuk melaksanakan kegiatan pembangunan tertentu.

Pada dasarnya tiap-tiap pelaku pembangunan khususnya para petani mempunyai kebebasan memilih, jenis pembangunan food estate apa yang akan mereka lakukan, bagaimana caranya, dan bilamana pembangunan itu akan dilakukan, untuk apa hasilnya nanti akan digunakan, dan sebagainya. Tetapi di dalam melakukan haknya untuk memilih, mereka selalu, mereka selalu dipengaruhi oleh dua hal pokok yaitu:

1. Oleh kesediaannya sendiri,

2. Oleh keadaan yang ada di sekelilingnya, yang terdiri dari modal, skill, tenaga, alam, dan kebutuhan akan bertambahnya hasil.

Dua hal ini tidak berdiri sendiri, tetapi saling mempengaruhi, kesediaan dapat mempengaruhi keadaan sekelilingnya dan sebaliknya keadaan sekelilingnya dapat mempengaruhi kesediaannya secara terbatas.

Modal dan skill merupakan unsur pokok yang menentukan keadaan di sekeliling petani. Kurangnya modal dan skill tersebut biasanya dapat menghambat pembangunan. Berhubungan dengan itu, maka pemerintah mempunyai 
kesempatan untuk mengarahkan hak pilih daripada petani dengan mengatur keadaan yang ada di sekitar petani. Jika keadaan yang ada di sekitar petani dapat sepenuhnya diatur oleh pemerintah maka dapat dipastikan bahwa pilihan petani akan jatuh pada arah yang dikehendaki oleh pemerintah. Sebaliknya jika hanya sebagian saja yang dapat diatur pemerintah maka petani akan hanya sebagian pula sesuai dengan kehendak pemerintah.

Secara lebih terperinci Mosher (1978) mendefinisikan faktor-faktor yang mempengaruhi pilihan petani, yang sekaligus juga merupakan faktor-faktor yang dapat dipergunakan oleh pemerintah untuk melaksanakan program pembangunan pertanian.

Faktor utama (mutlak) yaitu faktor-faktor yang harus ada supaya pembangunan pertanian dapat berlangsung, terdiri dari :

1. Pasar untuk hasil produksi

2. Teknologi maju

3. Tersedianya sarana produksi (alatalat dan bahan-bahan) secara lokal.

4. Perangsang Produksi

5. Pengangkutan.

Faktor pelancar (akselerator) yaitu faktor-faktor yang dapat mempercepat terjadinya pembangunan pertanian, yang terdiri dari :

1. Pendidikan Pembangunan

2. Kredit produksi

3. Kegiatan gotong royong oleh para petani

4. Perbaikan dan Perluasan Tanah Pertanian

5. Perencanaan Nasional untuk Pembangunan Pertanian

Lima syarat utama secara keseluruhan ibarat sebuah roda dengan lingkaran penuh. Roda yang bulat penuh tersebutlah yang dapat bergerak maju sehingga pembangunan pertanian akan dapat bergerak maju. Sedangkan syaratsyarat pelancar akan memperlancar berputarnya roda tersebut seperti halnya minyak pelumas atau ban yang memperlengkapi roda tersebut.

\section{PENUTUP}

Dari uraian-uraian terdahulu dapat diperoleh beberapa kesimpulan sebagai berikut :

1. Pembangunan Food estate di Kalimantan Tengah yang merupakan salah satu Program Strategis Nasional 2020-2024 yang bertujuan membangun lumbung pangan nasional, akan dilakukan dengan intensifikasi lahan pertanian atau mengoptimalkan pemanfaatan lahan eks PLG dan non eks PLG yang sudah ada dengan cara meningkatkan indeks pertanaman.

2. Program dan Implementasi Food Estate sebelumnya dapat dideskripsikan sebagai berikut :

a. Kesuksesan pengagendaan isu pangan ini didorong oleh beberapa faktor yaitu keberadaan isu yang memang mengancam, keinginan politik aktor dalam sekuritisasi, bayangan keuntungan masa depan yang akan didapat, juga jejaring lokal dan nasional yang dibangun untuk mendukung proses tersebut. Sedangkan faktor yang memperlemah sekuritisasi adalah kondisi politik yang kerap berubah seiring bergantinya kebijakan juga kekuatan yang dimiliki oleh veto para aktor dalam membangun jejaring untuk menentang sekuritisasi.

b. Terdapat disjungsi antara kebijakan terkait keamanan 
pangan dan bentuk-bentuk kemiskinan pangan yang dialami, menimbulkan pertanyaan mengenai konsistensi internal kebijakan, dan merekomendasikan mencari pendekatan baru yang sesuai dengan konteks tertentu dan yang dapat ditingkatkan.

c. Akibat implementasi yang belum matang, capaian keberhasilan MIFEE pada saat ini masih relatif lambat. Oleh karena itu, perlu dicari alternatif solusi agar MIFEE dapat menjadi tonggak sejarah sekaligus legacy pembangunan pangan untuk generasi mendatang. Permasalahan MIFEE dari segi investor, kelembagaan, perundangundangan, sosial, budaya dan politik dianalisis dan dicarikan solusinya.

d. Telah diidentifikasi sejumlah masalah dalam meningkatkan produksi beras, seperti penguasaan lahan, kesesuaian lahan, sistem air, infrastruktur, aksesibilitas faktor produksi, kelembagaan, dan kapasitas sumber daya manusia. Tiga yang program paling penting adalah pengelolaan air, peningkatan akses ke faktor produksi, dan meningkatkan kapasitas sumber daya manusia.

e. Pengambilalihan hak atas tanah dari masyarakat petani guna pelaksanaan program food estate di Kabupaten Bulungan Provinsi Kalimantan Timur dan Kabupaten Merauke dikaitkan dengan batas maksimum luas tanah yang dapat dimiliki oleh perorangan maupun badan hukum berdasarkan UndangUndang No. 56 Prp Tahun 1960
Tentang Penetapan Luas Tanah bertentangan dengan PP No. 18 Tahun 2010.

f. Proyek modernisasi pertanian dalam skala luas di Merauke dan Bulungan bukanlah usaha menjaga ketahanan pangan, melainkan semata ekspansi agribisnis dalam skala luas. Penyelenggaraan transmigrasi pada dasarnya hanya menjadi penopang untuk memfasilitasi ekspansi agribisnis yang terjadi di Merauke dan Bulungan. Kajian ini telah membuktikan kondisi kerawanan pangan yang harus dihadapi petani transmigran dan penduduk lokal terdampak proyek.

3. Pemberdayaan pertanian lokal sebagai solusi yang ditawarkan untuk keberhasilan Program Food Estate adalah sebagai berikut :

a. Pelaku utama pembangunan food estate di Kalimantan Tengah ini terutama adalah para petani setempat. Kewajiban pemerintah yang utama adalah membantu mereka dengan menjalankan berbagai usaha yang dapat menciptakan suatu iklim, di mana para pelaku pembangunan ini bersedia dan mampu melakukan pembangunan Food Estate yang sukses sebagaimana yang diharapkan.

b. Setiap pelaku pembangunan khususnya para petani mempunyai kebebasan memilih, jenis pembangunan Food Estate apa yang akan mereka lakukan, bagaimana caranya, dan bilamana pembangunan itu akan dilakukan, untuk apa hasilnya nanti akan digunakan, dan sebagainya. 
Tetapi di dalam melakukan haknya untuk memilih, mereka selalu dipengaruhi oleh dua hal pokok yaitu (a) Oleh kesediaannya sendiri, dan (b) Oleh keadaan yang ada di sekelilingnya, yang terdiri dari modal, skill, tenaga, alam, dan kebutuhan akan bertambahnya hasil. Berhubungan dengan itu, maka pemerintah mempunyai kesempatan untuk mengarahkan hak pilih daripada petani dengan mengatur keadaan yang ada di sekitar petani.

c. Faktor-faktor yang mempengaruhi pilihan petani, yang sekaligus juga merupakan faktor-faktor yang dapat dipergunakan oleh pemerintah untuk melaksanakan program Food Estate terdiri dari faktor utama dan faktor pelancar. Faktor utama (mutlak) yaitu faktor-faktor yang harus ada supaya pembangunan pertanian dapat berlangsung, terdiri dari : (a) Pasar untuk hasil produksi, (b) Teknologi maju, (c) Tersedianya sarana produksi (alat-alat dan bahan-bahan) secara lokal, (d) Perangsang Produksi, dan (e) Pengangkutan. Faktor pelancar (akselerator) yaitu faktor-faktor yang dapat mempercepat terjadinya pembangunan pertanian, yang terdiri dari : (a) Pendidikan Pembangunan, (b) Kredit produksi, (c) Kegiatan gotong royong oleh para petani, (d) Perbaikan dan Perluasan Tanah Pertanian, dan (e) Perencanaan Nasional untuk Pembangunan Pertanian.

\section{DAFTAR PUSTAKA}

Fatah, L., 2007. Dinamika Pembangunan, Pertanian dan Pedesaan. Pustaka Banua. Banjarmasin.

Kamin, ABM dan Altamaha, R., 2019. Modernisasi Tanpa Pembangunan Dalam Proyek Food Estate di Bulungan dan Merauke, Bhumi, Jurnal Agraria dan Pertanahan, vol. 5, no. 2, hlm. 163-179. DOI: 10.31292/jb.v5i2.368

McCarthy, J.F., and K. Obidzinski, 2015. Responding to food security and land questions: Policy principles and policy choices in Kalimantan, Indonesia. BRICS Initiatives for Critical Agrarian Studies (BICAS).

Mosher, A.T., 1978. Menggerakkan dan Membangun Pertanian. CV. Yasaguna, Jakarta.

Putri, A., 2019. Pengagendaan Isu Pangan Sebagai Isu Pangan Pada Pemerintahan Susilo Bambang Yudhoyono (Sby) : Studi Pada Kebijakan Food Estate. Jurnal PIR Vol.4 No. 1. ISSN:2528-7192. Jakarta.

Sagala, MDS., 2018. Peralihan Hak Atas Tanah Petani Melalui Program Food Estate Dikaitkan Dengan Batas Tanah Maksimum Kepemilikan Tanah. Tesis, 
Fakultas Hukum, USU.

http://repositori.usu.ac.id

Santosa, E., 2014. Percepatan Pengembangan Food Estate Untuk Meningkatkan Ketahanan Dan Kemandirian Pangan Nasional. Risalah Kebijakan Pertanian dan Lingkungan, Vol. 1 No. 2, Agustus 2014: 80-85. Bogor.

Setyo P and Elly J, 2018. Problems Analysis on Increasing Rice Production Through Food Estate Program in Bulungan Regency, North Kalimantan. IOP Conf. Series: Earth and Environmental Science 147 (2018) 012043. doi :10.1088/1755-

$1315 / 147 / 1 / 012043$

Prasetya A.W., 2020. Pembangunan "Food Estate" di Kalteng Tidak akan Buka Eks Pengembangan Lahan Gambut. Harian KOMPAS, 09 Agustus 2020

Bahfein, S., 2020. Food Estate 165.000 Hektar Eks Lahan Gambut Siap Berproduksi Tahun 2022. Harian KOMPAS, 10 Agustus 2020 